\title{
Ali Salem's The Comedy of Oedipus: You're the One Who Killed the Beast (1969)': A Classical Tragedy Revisited
}

\author{
Marwa Essam Eldin Fahmi Al-Kkhayat
}

Associate Professor of Comparative Literature \& Criticism, College of Foreign Languages \& Translation, English Department, MISR University for Science \& Technology, Giza, Egypt

marwa. fahmy@must.edu.eg

\begin{abstract}
The aim of the present study is to highlight the 'replay' of the master classic narrative: The Comedy of Oedipus: You're the One Who Killed the Beast ${ }^{2}$ (1969) by Ali Salem. This 'appropriation' gives room for renegotiating fixed political authority of post-independence dictatorship. This juxtaposition, consequently, is an endeavor on the part of the artist who experiences 'internal colonialism'. It is the hypothesis that Ali Salem 'reworks' the classics within a post-independence context to invest it with more local flavor dissociating it from authority and authenticity. Thereby, Salem manipulates the trope of parody as a key site of resistance to imposed values and practices. In the appropriated play, the Egyptian playwright dramatizes the ascending of the Egyptian Oedipus to power portraying him as a god and as a despot as well. Thus, this present study analyzes the intertextual relations between the old play and the new version. The ultimate aim, besides the unlocking of the underlying message, is to shed light on the rationale behind such relations. In this sense, the current paper seeks to examine the semiotic clefs and sign-systems that unfold the underlying structure of The Comedy of Oedipus especially within the text-performance axis.
\end{abstract}

Keywords: Classical Myths, Grotesque Comedy, Post-Independence Egyptian Drama, Intertextuality

\section{Introduction: Scope and Rationale}

Sophocles's Oedipus Rex occupies a high position in the literary tradition inspiring many artists to 'rewrite' the play in order to investigate different viewpoints. Herein lies the significance of the intertextual complementary relationship between the original myth and its reworking. The Comedy of Oedipus has been hailed by many critics especially Ali Al-Rai who wrote the "Introduction" to the Arabic edition in which he states that Salem has been under the spell of the Brechtian theatre which is manifested in a new form in a Greek tragedy. "Salem's intertextual enterprise", as Al-Rai states clearly, "is meant to demystify the concept of individual heroism which is no longer adequate in the second half of the twentieth century" (Al-Rai, p. 7).

Nihad Seleiha -in "Manifold Oedipus"- presents a comprehensive survey of the early Egyptian plays which tackled Sophocles's Oedipus Rex after a long neglect of this myth for its "taboo relationships": "in 1949, Tawfiq El-hakim and Ali Bakatheer published their versions... in 1968 Fawzi Fahmi wrote The Return of the Absent... Ali Salem's hilarious political satire in the vernacular You Who Killed the Beast... All view the myth from a political perspective... waving aside the central conflict between Oedipus and the gods and the centering the plot on a power-struggle, riddled

\footnotetext{
${ }^{1}$ The current paper is adapted from my PhD. Dissertation entitled, Post-Independence Drama from Utopia to Dystopia in Selected plays by Wole Soyinka and Modern Egyptian Dramatists, submitted to the Department of English Language and Literature, Faculty of Arts, Cairo University, 2010, supervised by Prof. Amal Aly Mazhar, Panel Committee: Prof. Nihad Seleiha and Associate Prof. Naglaa Al-Hadidy.

${ }^{2}$ All the translations rendered in Salem's Oedipus come from Carlson's The Arab Oedipus: Four Plays (2005).
} 
with conspiracies" (Al-Ahram Weekly, Dec., 2001). She elucidates that both Fahmi's and Salem's are a response to the 1967 war, but Salem's Oedipus is " a thin disguise for Nasser who was blamed for shutting himself off from his people, leaving them an easy prey to his demonic clique"(Al-Ahram Weekly, Dec., 2001).

The aim of the present study is to highlight the 'replay' of the master classic narrative: The Comedy of Oedipus: You're the One Who Killed the Beast (1969) by Ali Salem. This 'appropriation' gives room for renegotiating fixed political authority of post-independence dictatorship. This juxtaposition, consequently, is an endeavor on the part of the artist who experiences "internal colonialism" (Gilbert, \& Tompkins, 1996). It is the hypothesis that Ali Salem 'reworks' the classics within a post-independence context to invest it with more local flavor dissociating it from authority and authenticity. Thereby, Salem manipulates the trope of parody as a key site of resistance to imposed values and practices. This highlights the fact that the "dramatic text is one which is inscribed in a social formation and in a specific historical moment, but the contemporary stage production of a text (which is simply a contextualized reading of that text) may alter and re-articulate the original discursive formation" (De Toro, 1995, p. 10). In the appropriated play, the Egyptian dramatist dramatizes the ascending of the Egyptian Oedipus to power portraying of him two pictures as a god and as a despot as well. Thus, this present study analyzes the intertextual relations between the old play and the new version. The ultimate aim, besides the unlocking of the underlying message, is to shed light on the rationale behind such relations. In this sense, the current paper seeks to examine the semiotic clefs and sign-systems that unfold the underlying structure of The Comedy of Oedipus especially within the text-performance axis.

The Comedy of Oedipus can be analyzed quite independently of the original classical drama. The subject-matter is grimly realistic in which laughter and tears are explored, a point referred to by Egyptian critic Galal Al-Ashry:

The hero without heroism, the tragedy without tears: these expressions have dominated the Egyptian theatre in the second half of the twentieth century .... The Egyptian drama has deployed this type of comedy in which there is no blend between tears and laughter (Al-Ashry, 1971, p. 83)

It is "a deliberate grotesque version of the legend which retains hardly any of the ingredients of the original story" (Badawi, 1987, p. 202). The modern 'rewriting' is developed along a fantastic line in which "the events violate the normal constraints of time and space in a way that we expect of fantasies" (Barakat, 1975, p. 90). That is because " the hero is brought low, in Salem's world of fantasy, real heroism no longer exists" (Barakat, 1970, p. 90). Ironically, this explains the title of the play as it slips imperceptibly into tragic comedy.

In his "Introduction" to The Comedy of Oedipus, Salem states that he has reached two significant conclusions: the first is that the real source of the myth comes from the real events which already happened to the famous Pharaoh king Ikhnatoon as narrated in Oedipus and Ikhantoon by Russian writer, Emmanuel Vilkovesky. This idea is reinforced by the fact that Sophocles was a close friend to Herodotus who used to visit Egypt learning about its customs, rituals and stories. The second is that the myth -as an entity- is a source of limitless inspiration in which you can delete what is irrelevant and add what makes the work new, unique and contemporary (Salem, p. 20). This is manifested in Salem's dramatic equation as he puts it:

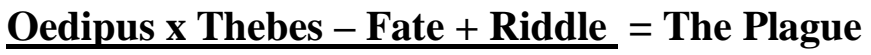

\section{The Beast}

Salem's play is a tragedy of a nation that deserves to be plagued because the Thebans have given up their roles in determining their lives and fighting the Beast without hiring anyone else to do the job for them. 


\section{Double Concretization' and 'Playful Transposition': The De-mythification of Oedipus Rex}

Terry Eagleton stresses the fact that the notion of "influence" has become inadequate, thus, it changes its meaning from the conventional sense to "the more radical sense that every word, phrase or segment is a reworking of other writings which precede or surround the individual work" (Italics mine, p. 138). The 'reworking' of the old material by Salem is induced by the socio/political conditions, a view which coincides with Catherine Belsey's belief that the text which "no longer the center of a self-contained exercise called literary criticism. It is one of the places to begin to assemble the political history of the present" (Belsey, 1986, p. 408). In the appropriated play, the Egyptian dramatist portrays two pictures of ruler seen as a god and as a despot as well. He dramatizes the ascending of the Egyptian Oedipus to power.

Thus, this present study analyzes the intertextual relations between the old play and the new version. The ultimate aim, besides the unlocking of the underlying message, is to shed light on the rationale behind such relations. This foregrounds a "textualization of ideology" (De Toro, 1995, p. 112): "The ideologization of the text is not only a productive act of the producer who disseminates the ideological components of his or her text, but also by the receiver of the message, who ideologizes the text from places of indeterminacy as textual blanks" (De Toro, 1995, p. 112). In other words, "the producer of the text (author or director)", as De Toro argues, "performs a semanticization of the fiction which is in turn convergently or divergently re-semanticized by the receiver. If the director is working with an old or distant text, he or she may semanticize it by bringing the fiction closer to our reality, or by making the text allude to the present reality without being too explicit" (De Toro, 1995, p. 113).

Myth's vitality is its inspiring influence to conjure up a new text added to the literary legacy. The revised myth is not a mere replica of the original one. Salem keeps a conscious eye on the myth he reworks so as to offer a new interpretation. Salem's bold attempt to appropriate Oedipus Rex is in line with W. J. Bate's advice: "to lift the burden of the past" is to learn "the value of boldness" (Bate, 1970, p. 132). The Comedy of Oedipus is recognizably derivative, yet it is genuinely different. Within this rationale, Harold Bloom believes that "influence" inescapably involves a drastic "distortion" of the work of a predecessor:

Poet in influence -when it involves two strong, authentic poets- always proceeds by a misreading of the prior poet, an act of creative correction that is actually and necessarily a misinterpretation ....

the main tradition of Western poetry since the Renaissance, is a history of anxiety and selfcaricature, of distortion, of perverse, of willful revisionism. (Italics mine, Bloom, 1973, p. 30)

In this sense, Salem's imagination is seized by Sophocles's Oedipus Rex and to safeguard his own sense of "autonomy", the "belated" dramatist "swerves away" from his precursor to execute a "discontinuous" and a "corrective" movement in an "antithetical" manner. This questions Salem's "originality", i.e., differences occur in the belated encounter text, that is, Salem's individual parts that help him compete with Sophocles antithetically. The question of originality is meant to be "open" and "elusive", not "a stagnant pool ", but as "friction or tension between the poet and his tradition, the present and the past, the new and the old works of art" (Zeid, 1990, p. 18).

The myth of Oedipus brings to the fore Barthes's attempt to differentiate between Work and Text within the frame work of 'method': "The Work is a fragment of substance occupying a part of the space of books (in a library for example), the Text is a methodological field. (Barthes, 1971, p. 157). Within this rationale, Salem's The Comedy of Oedipus is a 'Text' that has 'methodologically' deciphered the old myth. To define Text, Barthes argues that "A text is not a line of words releasing a single "theological" meaning (the "message" of the Author-God) but a multi-dimensional space in which a variety of writing, none of them original, blend and clash. The Text is a tissue of quotations drawn from the innumerable centers of culture" (Italics mine, Barthes, 1968, p. 146). 
Salem's Text, therefore, 'misinterprets' the original myth in many dramatic points. Oedipus does not kill his father or marry his mother, Jocasta does not commit suicide nor does Oedipus blind himself. This 'willful misinterpretation' is meant to "shift the dilemma of Oedipus entirely from the personal to the political plane, to the disintegration of public life under the rule of the corrupt politicians, priests and academics" (Carlson, 2005, p. 11). The major part of the myth retained is Oedipus's encounter with the Sphinx. It is central to Salem's adapted version because it is associated with the evil deeds of Oedipus's cult of personality. This is vocally metaphorized in the mindless chant of the play's subtitle: "You're the One Who Killed the Beast".

Salem's astuteness lies in his bold resort to comedy. This enables him to escape any kind of comparisons with the original drama on the one hand and to present a different approach from the other old enterprises of appropriating the ancient myth on the other one. Salem's modern version has been hailed as " a revolutionary writing within the context of resistance literature"(Al-Haqaqi, p. 94). This is attributed to Salem's merciless attacks on corruption and despotism. The Egyptian adaptation "calls attention to the peril of having a system of internal control so powerful that it cannot be monitored or checked, and finally, it exposes the vulnerability of a ruler blinded to the real situation of his state" (Barakat, 1970, p. 92).

Salem's first point of departure is a deliberate grotesque of a society that has institutionalized aggression and violence rendered in a sardonic tone. In contrast, Sophocles's is a personal tragedy of the focal character, namely, a tragedy which produces a deterministic world-wide view. To my mind, Salem introduces an "anti-hero", a term defined by Styan as " a character capable of suggesting complexity .... he has implicitly two or more sides .... He calls for two or more responses, positive and negative, and all the shades between" (Styan, 1968, p. 270). Prominent Egyptian critic Ali Al-Rai comments on Salem's choice of an old Greek myth by saying that "what concerns Salem is neither the incestuous marriage nor the predestinated fate, but the individual's role in relation to the course of history" (Rai, p. 7). For him, Salem satirizes the belief in one's personal abilities to save the whole humanity as Oedipus does in the myth" (Rai, p. 9) and as Nasser claimed to do for the Egyptians.

Salem's revisionism of the old myth asserts Barthes's ridicule of regarding myth as something that transcends history. Barthes believes that the roots of a myth lie in socio-political conditions:

One can conceive of very ancient myths, but there are no eternal ones, for it is

human history which converts reality into speech and it alone rules the life and death of mythical language. Ancient or not, mythology can only have an historical foundation, for myth is a type of speech chosen by history. (Barthes, 1973, p. 110)

To achieve his movement of "discontinuity", Salem resets the ancient myth in Egypt. He delineates "Oedipus-Ra", the Sphinx and the Egyptian Thebes, not the Greek one. The temple of Delphi is replaced by that of Amon. Salem makes use of Egypt's famous landscape: The Nile and the Great Pyramid. He also creates new characters bearing pharaonic names: Onah, Senefru, Kami and Horimheb. Although Salem keeps the Greek names of Oedipus, Tiresias, and Jocasta, he changes their dramatic roles to suit his purpose. Salem's Oedipus is -by implication- Nasser. The Oedipus/Nasser affinity lies in the question of responsibility: If the both leaders are not held responsible for their nation's deification, they do not altogether escape the blame for adopting a political system based on repression and physical torture. To avoid the mechanical repetitions of the old names, the Eygptianised Tiresias is no longer absorbed in metaphysical meditations. That is because his prime concern is politics. Jocasta is a lustful woman and her role is part of the conspiratorial nature of Awalih's strenuous rule. Her presence also helps to assert that "Oedipus has become something of a 'hermit' or 'absent-minded professor'" (El-Lozy, 1990, p. 60). This can explain why he gives a blind eye to the internal security of Thebes. 


\section{The Tiresias/Awalih Binary: A Dialectical Conflict in the Dystopic Egyptian Thebes}

The dramatic script sheds light on a verbal battle which occurs between Tiresias, the old seer in the ancient myth, and Awalih, the modern chief of police. It is a battle between the will to keep the nation's consciousness dynamic and that of repression and suffocation. Tiresias stands for the voice of a dissenter whose holy mission, is not to worship Apollo or Oedipus, but to awaken the public's perception to the deceit and corruption that are planted by a ruthless man who is ironically in charge of protecting them. Why I have chosen this kind of polarity? In my contention, the play is a clash between reason and brute force which is manifested in the depiction of Tiresias and Awalih respectively. Awalih is the creator of "fear" that has been inflicted on the Thebans, while Tiresias takes upon himself the task of removing the dust from the Thebans' eyes to confront their gigantic enemy, "fear" that resides in their hearts, thus, makes them puppets.

What catches attention is Salem's traditional portrayal of Tiresias as the stage direction says: "From the depths of the stage, which is bathed in soft lights, comes Tiresias leaning on a stick" (Stage direction, p. 287). The dramatist himself announces that the old sage is "the same personage with the same well-known characteristics, as in the ancient Greek literature" (Stage direction, p. 286). Egyptian critic Naseem Megaly refers to the new depiction of Tiresias by the famous director Galal Al-Sharqawy who also performed the role on the stage in 1970:

On realizing the importance of Tiresias's role, Al-Sharqawy portrays a well-built young man full of energy and his long black hair dangling upon his ears, carrying a guitar while he is narrating the story of the wretched Thebes. However, the young Tiresias -like the ancient one- suffers from the same physical blindness. (Megaly,

$$
\text { 1984, pp. 24-25) }
$$

Megaly believes that the director's new dramatic vision is unique and useful. That is because the delineation of an Egyptian Tiresias is meant to make him "more positive to the extent of being revolutionary, possessing more courage than his Greek counterpart acting as a catalyst confronting opportunistic politicians with extreme strength and psychological firmness" (Megaly, 1984, p. 24). Yet, there is no need to maintain the same physical blindness since the young Tiresias is not a prophet in Salem's new version. He is meant to be a dissenter who knows the detestable truth about Awalih's moral infirmity.

In fact, the talented director's modification refutes the general assumption -made by some literary critics- of the priority of the written play over the performance. Salem's text is conditioned by its "performability" in relation to the portrayal of Tiresias. In this respect, performance is the written text's "stage contextualization" (Elam, 1980, p. 209). It is also regarded as "a linguistic transcription of a stage potentiality which is the motive of the written text" (Gulli Pughatti, 1976, p. 18). This modification gains theatrical vitality as Tiresias emerges in " the beetle-like appearance which bears modern implications: the long hair has become a symbol of rebellion, a feature which characterized the youth of the director's generation [in the late sixties] who reject all forms of suppression" (Megaly, 1984, p. 26).

In terms of stage performance, Al-Sharqawy fills what Ann Ubersfeld calls the "indetermination of the DT". Ubersfeld points out that the mediating factor between the dramatic text (DT) and the performance text (PT) is the production text (PRT) as manifested in the following model:

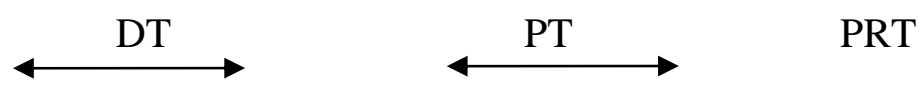

Figure 1 
The relationship is one of "reciprocity" (Ubersfeld, 1977, p. 15) since the PT is the contextualization of all the enunciative situations, the concretization of space, time, rhythm, movement, the text's ideology, proxemics, kinesics, contextualization of the utterance/enunciative situations. Consequently, De Toro explains the following:

One might say that the PT is the process of inscription of the dramatic text's potential. This is not a process of transcription, but rather, inscription, for the DT and the PT do not coincide. On the one hand, the places of indetermination are being filled, and on the other the staging potential is being inscribed. (De Toro, 1995, p. 49)

Thus, Al-Sharqawy fills this "indetermination of the DT" by his new depiction of Tiresias as a young dissenter. This suits the text's ideology which is meant to be full of resistance. However, we cannot neglect Salem's successful choice of Awalih's name. On the physical level, the lexicon 'Awalih' is the unnecessary parts of maize used for burning or making fire. On the symbolic level, Awalih, as an actant of political corruption, is an unnecessary part in the state's plans of progress and he is fit for nothing except intrigues. At this juncture, the Tiresias/Awalih relation is a dialectical one between integrity and criminality.

The depiction of Awalih gains weight through the theatrical manipulation of certain props: files of the Thebans, lists of criminals and hiding behind the curtain to spy on the king himself. " I just arrest them", as he says, "I am a very arresting man" (The Comedy of Oedipus, p. 301). He easily accuses the disobedient of being "anti-Amon" and planning for a "coup d' etat" (The Comedy of Oedipus, p. 301). When Oedipus is about to be elected by the masses, Awalih asks for Oedipus's file handed to him by his men saying "Oedipus: color of eyes-brown. Complexion -darkish. Distinguishing mark -swollen feet" ... (The Comedy of Oedipus, p. 299). What raises laughter is Awalih's confession that the Awalih family "has held the post of Chief of Police for four hundred years. I've noticed a strange thing: the lists bearing names of enemies of the regime are always the same. They've been passed on from father to son -sometimes one or two names more, sometimes one or two names less. But the lists have always been the same" (The Comedy of Oedipus, p. 309). Awalih's conspiratorial nature is dramatically associated with the curtain or Oedipus's throne. "Awalih is like the air -always to be found everywhere" (The Comedy of Oedipus, p. 343) as he describes himself. He imprudently spies on the king and the pretext which he gives is that "these are inevitable measures, my Lord. It's true they're not very pleasant, but they're necessary" (The Comedy of Oedipus, p. 310). Obviously, this refers to the notorious role played by the secret police under Nasserist regime. Herein lies Oedipus's fatal mistake since he relies on the machinations of a sly enemy [Awalih] to maintain his rule, thus, he starts to lose power and credibility.

The previous comic situation acquires a degree of seriousness by Tiresias's intrusion in the scene:

Tiresias: The worst horrors and the most intractable calamities always

begin thus, .... with things that are unpleasant but necessary.

(The Comedy of Oedipus, p. 310).

Tiresias is the only one who can abuse Awalih openly with no fears of these 'unpleasant measures'. Awalih's decision to arrest Tiresias for humiliating the Municipal Council is rejected by the Thebans and Creon -the Commander of the Guard who says ".... I will not allow anyone to be put under arrest merely because of his opinions. Regarding Tiresias .... no one can doubt his great love for the City ... (The Comedy of Oedipus, p. 296). Therefore, the Tiresias/Awalih dispute envelops the whole drama which aims at exposing post-independence shortcomings.

In a Brechtian geste, Tiresias's prologue sets the whole paradoxical tone of the play. He sets a contrast between two Thebes: the old "beautiful" and prosperous Thebes with "great temples, flourishing trade" (The Comedy of Oedipus, p. 287) and the current miserable "wretched" one (The Comedy of Oedipus, p. 287). This is an obvious shift from the utopian city to the dystopic one. The point is that if the socio-political affairs in Thebes were in the right course of direction, Awalih would be of no use, thereby, Tiresias's role would not be urgent. The struggle between moral integrity 
and that of moral infirmity is manifested in a number of theatrical devices to highlight postindependence dystopia.

\section{The Circular Structure: A Signifier of A Dysfunctional Thebes}

Salem's play is a combination of the different visual, aural and verbal structures that make-up the over-all shape of a dramatic performance. The present analysis will aim at showing the circularity of the play's structure which is revealed in distinct parts which can be apprehended as units or as the constituent elements of a larger structure. This highlights Esslin's view of dramatic structure as analogous to musical structure which "depends on the interaction, in sequence, and contrapuntally at any given moment, of melodic and rhythmic elements that are established, varied, juxtaposed, combined and recombined" (Esslin, 1987, p. 119).

Act One opens with the depiction of the Egyptian, "not the Greek Thebes" (Stage direction, p. 287). The portrayed scene is that of a typical pharaonic setting which consists of "a temple .... around which are some ram-headed sphinxes ...." (Stage direction, p. 287). There are also the stone benches used by the public to face the palace balcony. The time is "a very long time ago" (Stage direction, p. 287). It is obvious that the place is set in a remote past while the temporal dimension remains unspecified in order to universalize the Egyptian experience. It is a "political metaphor", as Marvin Carlson writes

Referring in this case to the recent history of Egypt and especially to Nasser, who in 1956 gained heroic stature .... but who then allowed his moral authority to be eroded by the cult of personality, the suppression of truth and the political

indoctrination of the mass media, while he turned his attention to technical matters and the improvement of the infrastructure. (Carlson, 2005, p. 10)

The stage direction also spots light on Oedipus's proxemics: "at the front of the stage, engrossed in a peaceful game of chess"(Stage direction, p. 287) with his friend Kami. Chess is known to be the game of astute, clever men, yet, it symbolizes Thebes that is going to be governed by Oedipus whose role will be diminished by amoral politicians. History says "checkmate" to Oedipus at the finale of the play announcing his defeat in fulfilling his lofty ideals.

The final Act is "the same as at the beginning of the play" (Stage direction, p. 331). The people are sitting on the stone benches in utter "gloomy silence" (Stage direction, p. 331), a physical state which is a signifier of complete surrender to the political turmoil after the return of the beast. Tiresias's prologue in the introductory scene in Act one is replaced by Awalih's political speech in the opening scene of Act three. This juxtaposition encircles the whole play within the physical/moral blindness polarity. In other words, Tiresias's prologue foreshadows Thebes's grim destiny if it fails to face the real beast that threatens the Thebans' lives while that of Awalih is a mere justification of the military defeat. The play closes with Tiresias's epilogue while he is "at the front of the stage" (Stage direction, p. 350). This exchange of the theatrical position between Oedipus and the old seer clearly manifests Tiresias's moral vision which wins at the end of the play despite Oedipus's intellectual greatness.

Act Two is designed in an episodic structure, i.e., it embraces vibrant, short, quick scenes or sketches reflecting the Thebans' ridiculous life. The originality of Act two lies in the extensive use of anachronisms. The setting has "altered features: there is a multitude of shops .... selling the most modern devices ...." (Stage direction, p. 327). Scene one sheds light on Senefru's living room in which "the furniture is semi-modern" (Stage direction, p. 311). There is also a large television, a radio, and a telephone" (Stage direction, p. 311). This is an important theatrical tool so as to break "make-believe" or what Brecht calls an "effect of estrangement" to break down the audience's readiness to accept illusion in order to induce a "critical attitude" toward the events shown (p. 191). This is in line with Styan's words: "the stage and the auditorium must be cleared of all 'magic' 
elements, and no 'hypnotic fields' are to be set up by atmospheric settings ...." (Styan, 1960, p. 232). In this respect, Salem's collective picture of the Thebans reflects their mental stagnation, cherishing unreal peace, because they think that they are safe as their affairs are handled by an honest administration (Al-Rai, p. 9).

To refute M. El-lozy's assumption of the play's weak structure, the succession of scenes, stylistically speaking, is meant to create an "impression" that is a reflection of the general effect of the whole play or - to use Styan's analysis- "the interest in the drama creates and recreates impressions that move in a progression exactly determined by the progression in the line of action" (Styan, 1960, p. 68). Styan introduces his concept of 'impression' diagrammatically:

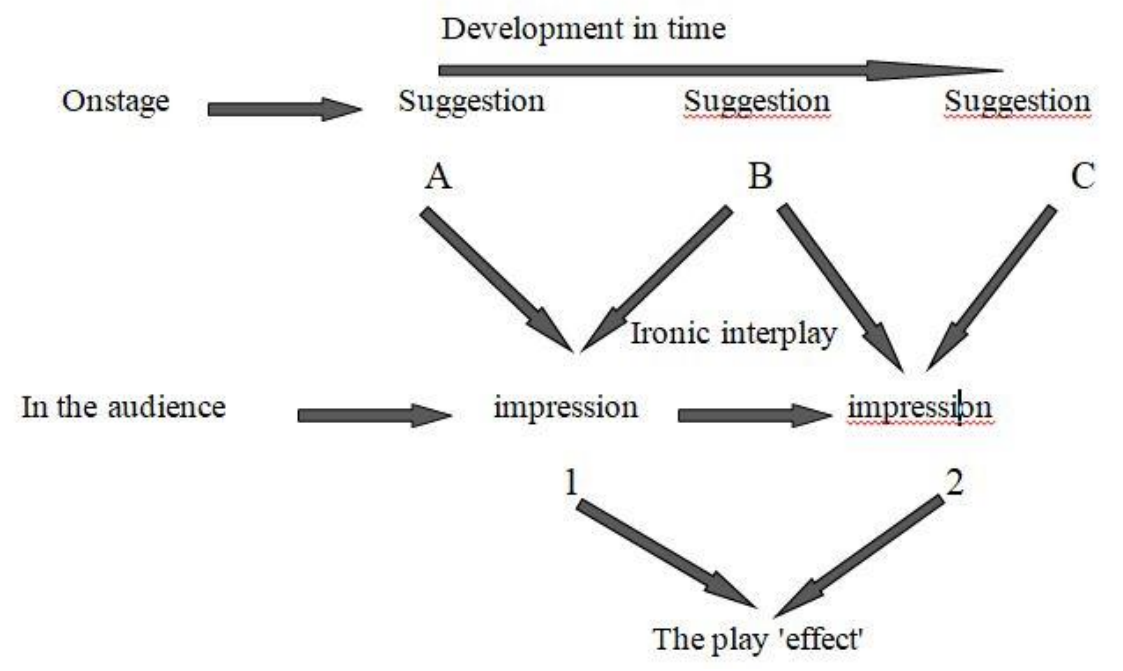

Figure 2

The good critic measures and assesses the development between impression 1 and impression 2, a development which is the true source of effect in a play. Impressions are received by the dramatic process of ironic deduction (Styan, 1960, p. 68).

By application, scene One exposes the private life of the artist, Senefru. He is haunted by the ridiculous slogan "you're the one who killed the beast" as concretized in a number of items: his child's toys take the shape of " a beast riding a bicycle with Oedipus killing a beast; a beast on a plane with Oedipus killing it; a beast playing ball with Oedipus killing it ...." (The Comedy of Oedipus, p. 312). While watching television, Senefru finds a literary program presenting the comedy "Don't Be a Beast to Me and I Shan't Be a Beast to You" (The Comedy of Oedipus, p. 313). Scene Two takes place in a lecture hall in the University of Thebes. Horimheb implants in the students' minds the fact that "no human could solve the riddle unless he was descended from the gods":

Horimheb: This is why Oedipus was able to do it. I refer you to pages 15 to 340 of our own doctoral dissertation, in which we spoke at length of the divine origins of His Majesty

Oedipus-Ra. (The Comedy of Oedipus, p. 314)

Scene Three is "a narrow tomb inside a temple" (Stage direction, p. 315). Awalih is interrogating Kait, one of the citizens in Thebes. He is "tied to a stone pillar; beside him is a very young policeman" (Stage direction, p. 315):

Kait (In great weariness, speaking with immense difficulty):

Listen, Awalih, I'm tired of this game. Every time a new king is enthroned, you get hold of me, beat me in the same say, and ask me the same damned questions .... I'm losing all faith - or perhaps one is better off dying .... (His head sinks to his chest).

(The Comedy of Oedipus, p. 316) 
The young policeman announces Kait's death, then he engages in a ludicrous dialogue with Awalih who bluntly fabricates Kait's "theft of the treasures of Ra" (The Comedy of Oedipus, p. 316) ordering the policeman to throw the dead body from the roof:

Policeman: Didn't you say there were no windows on the fourth and fifth floors?

Awalih: (Very angrily) Why do you have to complicate things for me? Policeman: (Totally rattled) I'm sorry .... Please go on to the cinema - or- you might miss the Mickey Mouse cartoon. (The Comedy of Oedpius, p. 317)

Scene Four shows the royal throne room in which Jocasta is seen restless and sexually frustrated pushing Awalih to get rid of Oedipus as he did with "his predecessor and the predecessor's predecessor. An accident of this kind that takes place every day. Who can be sure of his own life?"(The Comedy of Oedipus, p. 318), as she says. This conspiracy does not appeal this time to Awalih because influential persons are making a living out of Oedipus's inventions, and "if anything happened to Oedipus, they wouldn't keep quiet, and we, my lady, would be exposed" (The Comedy of Oedipus, p. 319), as he replies.

From the previous illustrations, the most dominant feature is that of 'ostension', i. e., "the showing of events rather than describing or explaining or defining them" (Elam, 1980, p. 30). This presents "the stage spectacle as a 'display' " (Italics mine, Elam, 1980, p. 30). Such a 'display' is characterized by the heterogeneity of its spatio-temporal structure that covers the whole Thebans' deformed life. In a Chekovian manner, Salem supplies a substitute for action in order to evoke a mood within this 'display' which acts as an overwhelming pressure of feeling upon the audience. In other words, there is a mixture of the comic and the pathetic in the depiction of his episodes, thereby; the 'laughter and tears' theory of Chekhov is carried out. Mixing contrasting moods within a scene is meant to shock the audience into an acute perception: "a purposeful shock may arise with the switch from a comic to a tragic mood, or vice versa, felt within the continuity of a scene" (Styan, 1960, p. 190). Consequently, the comic zest is largely the result of the rapid and direct succession of conflicting impressions about Oedipus's inventions: are they a curse or a blessing? Herein lies Styan's idea of the 'sequence of impressions' as it marks the success of the play's "line of intention" (Styan, 1960 , p. 121) which is the play's theme that is communicated by the whole theatrical experience.

Foregrounding the dramatic events within "the method of identifying the underlying grammar of the play's structure" (1991, p. 80), in Aston's and Savona's words, also stresses the circularity of the plot. The actantial configuration -operating in this circularity- can be seen as a sign-system of the gap between the lofty ideals and the shattering reality. As the play progresses, Oedipus embodies the 'Thematic Force' of 'ambition'. The 'Good Sought' is the crown of Thebes and the 'Potential Receiver' of the 'Good' is Oedipus himself. The 'Desired Good' is attributed to Oedipus by his intellectual greatness. Yet, the protagonist's path is blocked by Tiresias who is against Oedipus's decision to go by himself to confront the beast. This centralizes the message of the play, the rejection of individual heroism.

When Oedipus's "ambition" is fulfilled, a new 'Thematic Force' arises which is "fear" as embodied by Awalih. As a result, the 'Desired End' becomes "suppression" and its 'Potential Receiver' is a mélange of liars and cheaters: Onah, Jocasta, Horimheb and of course the chief composer of this corruption, Awalih. The 'Desired Good' is attained by adopting ruthless laws to torture the dissenters. The 'Opponents' are still Tiresias and Senefru. They are both always in a state of disillusionment from the outset of the play.

The emergence of a new 'Thematic Force' stresses the circularity of the structure in being a concrete proof of Oedipus's deteriorated leadership. Oedipus has been elected by the population, a step which raises the expectations of a political change under his rule. These expectations are aborted when Oedipus shows no interest in Thebes's internal affairs, thereby, becoming a silent accomplice by giving Awalih a free hand to act as he pleases: " you're supposed to know your business efficiently 
and your business is the maintenance of Thebes's internal security " (The Comedy of Oedipus, p. 309).

Finally, it is noteworthy that the circular structure is enveloped in the repetition of the ridiculous chant "you're the one who killed the beast". This repetition stands for a rhetorical and stylistic coherence as it evokes a dramatic "idiolect" which is clarified by Elam: "A powerful dramatic text will create its own 'idiolect', an overall style characterized by recurrent syntactic and rhetorical pattern, lexical iteration (repetition and variation of the same words and phrases) (Elam, 1980, p. 183). It is the rhythmic structure of the different strands of signifiers which render a complex contrapuntal structure. This keeps the audience's focus alert and constantly renewed. On this point, Esslin argues that

However, fascinating and interesting the action may be on a purely conceptual intellectual level, without that underlying variety and movement it would inevitably become monotonous and dull and hence the spectator's flagging attention induced purely physiologically by monotony, would lead them to lose the intellectual thread. The rhythmical structures of interweaving strands of signifiers are the true 'texture' that keeps a dramatic text alive. (Italics mine, Esslin, 1987, p.

In a word, the circular structure manifests a cluster of signifiers to offer a rich profusion of rhythmical, visual, melodic and tonal pattern.

\section{The Lighting Scheme: The Dystopic Interplay of the Outer/Inner Darkness of Thebes}

Esslin argues that "the most important function of light in dramatic performance is deictic. It is the lighting that can direct attention to the focal points of action, almost literally an 'index' finger pointed at the area of maximum interest" (Italics mine, Esslin, 1987, p. 76). In terms of iconic function, Salem's use of light is meant to mark the shift from one scene to another especially in Act Two which is episodic in design. The use of light is also expressive of gloomy conditions and can display symbolic effects as well.

First, the lighting is "dimmed" and "the stage sinks into complete darkness" (Stage direction, 305) after Oedipus's victory. On the surface level, it marks Oedipus's regal status, i.e., he is seen among the populace in the open air sharing their views and opinions as revealed in the introductory scene in Act one. In contrast, when he is enthroned he is portrayed in the royal room "wearing the royal mantle and the crown" (Stage direction, p. 305). On the deeper level, the dimmed light foreshadows the utter darkness that will loom over Oedipus's eyes preventing him from seeing well the moral corruption of Awalih. As the play progresses, he is either seen in his laboratory -which has become a signifier of aloofness- or in the palace balcony which symbolizes his state of detachment

Second, the episodic scenes are rendered via the use of the puppet show technique as recommended by the dramatist himself in the stage directions: "blackened stage, ultraviolet rays, and projected shadows" (The Comedy of Oedipus, p. 311). Thus, this technique has become a vivid token of expression to stimulate the audience to apprehend the absurdity of the socio/political predicament of Thebes. In semiotic terms, this lighting scheme has become part of the stage indices or what Charles Peirce calls "focusing the attention" (qtd. by Elam, 1980, p. 26). The importance of the indexical sign-function is in pointing out where the spectator should direct his attention, a point emphasized by Partice Pavis: "the theatre which must constantly attract the receiver's attention will thus have recourse to the index" (qtd. by Elam, 1980, p. 26). In this sense, the spectators are suspended in the theatrical state of fantasy. In replacing the function of the stage curtain, light works in a manner of the filmic montage to mark the move from one scene to another. For example, it signals the shift from Senefru's living room to that of the lecture hall in which the dishonest professor displays the following: "a large screen lights up, and on it appears the shadow of OEDIPUS, gigantic 
around him" (Stage direction, p. 315). Scene Four in Act Two holds a dialogue between Awalih and Onah who both insolently expose their ugly reality regarding the fabricated myth behind Oedipus's divine nature, chanting " we're the ones who killed the beast!" (The Comedy of Oedipus, p. 320). Actually, they have tamed Oedipus imprisoning him in his lab to get the utmost materialistic benefit from him. In this dramatic note, the lights gradually dim to be switched on to see the Thebans "kneeling and chanting in voices filled with awe and devotion, as if praying. Oedipus stands before them" (Stage direction, p. 321):

\section{People: Oedipus-Ra .... You're the one who killed the beast ...}

(The Comedy of Oedipus, 321)

Herein lies the dramatic irony as it works in the larger narrative of the whole play. The question, thus, becomes who killed who? Oedipus unknowingly has deadened the spirits of the Thebans by his materialistic devices that answer only their physical needs. The Thebans have killed themselves by accepting Awalih's humiliating treatment. Both Oedipus and his people fall easy preys to the "national tradition" of worshipping kings as gods (The Comedy of Oedipus, p. 323), as Onah explains. That is because the act of idolization is not only a "pious custom", but it is also "a matter of prestige" (The Comedy of Oedipus, p. 325), as Horimheb continues. Awalih summaries the whole debate in the following words: "The truth is that your Majesty is still new at this trade ..." (The Comedy of Oedipus, p. 325). Therefore, Salem manages with the visual effects of switching off and on the light to present a dramatic pattern of fluctuations and movements of the characters via the meaning of the words-acted and the scene-set.

Third, the interplay of the physical/ moral vision is epitomized in Act Three, Scene Two that depicts the return of the beast. The scene encompasses Oedipus, Tiresias and Creon in an attempt to figure out what kind of malaise has afflicted the Thebans:

Creon: .... I don't know who's responsible for it? I don't know. Something wrong

with the species of man in this place, and whoever's responsible for that

flaw is necessarily responsible for the formation of man here.

(Italics mine, The Comedy of Oedipus, p. 341)

Oedipus is shocked by Tiresias's verbal blow:

Tiresias: You are also, my Lord, the author of the worst invention in history - Fear! .... Let fear worm its way into the heart of man and it mingles with blood, his intellect, his dreams .... At that point, man is no longer man. He becomes something brittle, and what's brittle easily crumbles.

(The Comedy of Oedipus, p. 342)

The scene ends with the union of Oedipus, Tiresias and Creon, a union visualized with an intensified light " on a single spot near the front of the stage .... the rest of the stage is in darkness" (Stage direction, p. 347). After that, the light gradually is extended to cover the whole stage to show Oedipus in a mental perplexed state saying "how faint the light is in the palace tonight. I can't see very well" (The Comedy of Oedipus, p. 348). This elucidates Aristotle's definition of "discovery": " a change into the reverse of what is expected from the circumstances of the action" (Aristotle, p. 25). Oedipus's harsh discovery of his failure as ruler acts contrary to what is expected. This signifies the hero's moment of illumination as he himself declares ".... I've discovered at the peak of my glory that there are still things that I don't know. I shall leave .... I shall set off on a long journey, in order to learn. Take my hand, Creon; show me the door. I thought it was the light that was faint .... (In distress) Ha! .... I didn't know the world could hold so much darkness .... (The Comedy of Oedipus, p. 349). Sophocles's chorus ends the play in a manner that is copied by Salem:

Chorus: Show me the man whose happiness was anything more than illusion followed by disillusion. (Sophocles, p. 59) 
Creon takes the brave decision to face the beast alone: "proudly marches through the square to which the light is gradually extended, with his head held high" (Stage direction, p. 349). Playing the role of a filmic montage, the lighting device is used to denote Creon's noble defeat: "the people gather round the corpse as the lighting is gradually restricted to a spot light on Tiresias at the front of the stage" (Stage direction, p. 350). In the closing scene, the lighting configuration underlines Tiresias's epilogue

Tiresias: .... And you people who live in this city and to whom I have told the

story of my city, know that although you were provoked to some

laughter as you listened to this story, I swear to you by all the gods

that that was not my intention. (The Comedy of Oedipus, p. 380)

I agree with El-Lozy's criticism of Salem's closing scene in which Creon undertakes the "unsuccessful repetition of what Oedipus had done by confronting the Sphinx alone" (El-Lozy, 1990, p. 59). That is because "this development is in direct opposition", as El-Louzy continues, "to the conscious message of the play on the subject of individual heroism" (El-Lozy, 1990, p. 59). Thus, Tiresias's comments on Creon's suicidal mission is laden with contradiction, yet, his final words are "tinged with a romantic yearning for a new great man to replace the defeated one" (El-Lozy, 1990, p. $63)$.

\section{Paralinguistic Aural Signifiers of Awalih's Intimidation and Censorship}

Regarding the case of linguistic codes, Elam argues the following:

A language is in reality a complex of codes ranging from denotational correlation rules to dialectical, paralinguistic, rhetorical, pragmatic and contextual rules, all of which go to make up the rich network of constraints regulating utterance and their meanings. Theatrical performance will engage a vast range of correlation rules of this kind .... Certain of these codes

(e.g. the kinesic, scenic or linguistic) will be specific to particular systems while others (theatrical and dramatic conventions and more general cultural codes) will apply to theatrical discourse at large. (Elam, 1980, p. 50)

In this section, the aim is to show how far the actor's kinetic signifiers are interwoven with his paralinguistic ones. Awalih's theatrical gestures contradict his linguistic utterances. The point is that the dramatic tension is between linguistic reference and kinesic signals. This is seen as a source of comic effect.

The Awalih/Senefru antagonism exposes the chronic abuse of power as bred in postindependence dystopia. The enmity of the two men is conceived in Salem's use of paralinguistic features to emphasize the fact that "a linguistic utterance is not simply a product of the phonological, syntactic and semantic rules of language" (Elam, 1980, 78). In other words, 'the conversational use of spoken language cannot be appropriately understood unless paralinguistic elements are taken into interpretation. Awalih's vocalic qualities [lip control and pitch range] are amplified by his [intensity and pitch height] to terrify and threaten Senefru. Their struggle is rendered in two comic dramatic situations. The first meeting dramatizes Awalih's contradiction between his menacing voice and his words:

Awalih: .... (Turning to the populace, and shouting menacingly) Have I

prevented any of you from speaking? (Some of the policemen standing by the move as if to encircle the public). Speak out!

Is there anyone who had something to say and doesn't know how to go about it? (Stretches out his hand, gets hold of one of those sitting, and pulls him up.) Senefru - speak! You're a playwright, and every year one of your plays is staged in the temple yard. 
(In a changed tone). It could have happened that nothing of

yours was presented, couldn't it?

Senefru: Yes.

Awalih: .... Go ahead and speak so that Mr. Oedipus should know that we have freedom of speech here.

Senefru (Whispering): Which play? The one you banned .....?

Awalih (In a low but rancorous voice): The one that was produced, you

fool! (Italics mine, The Comedy of Oedipus, p. 297)

and Senefru are at odds and their opposition lies in their professions. Being a Chief of Police, Awalih wages war against any honest and loyal writer whose sole weapon is his pen. This is emphasized theatrically in "a low but rancorous voice". This vocal index acts as a transmitter from which the audience can decode the message as delivered by the terrifying investigator. Furthermore, Awalih's vocalic characteristics are in conjunction with his kinesics as manifested in "stretching" his hands to "pull" Senefru. In other words, Awalih's gesture does not exist as an isolated entity, a point raised by Pavis to define the function of gesture which is the "capacity to sketch out the situation-ofutterance, to become deictic .... [gesture] is always geared to the stage through innumerable corporal deixes, beginning with attitude, glance .... (qtd. by Elam, 1980, p. 72). The comic 'effect' arises from the incongruity or tension between Awalih's linguistic reference and vocalic features.

The second dramatic encounter is during the national celebration of liberating Thebes from the beast. Awalih notices Senefru's detachment "from the masses as he stands away from the crowd, at the front of the stage" (Stage direction, p. 328). He is forced to sing by Awalih after being given a plain threat:

Awalih (With murderous gentleness): Senefru, why aren't you singing?

I've been watching you ....

Senefru (Trying to make his voice sound hoarse): It's just that my voice

has gone hoarse today.

Awalih: .... Well, then, whistle, or hum, show some response to the music ....

Senefru: It's just that I haven't a musical ear.

Awalih: .... The fact is that your ear is very musical indeed. It's just that it isn't clean and I am going to clean it for you .... (Whispering): Come with me, quietly .... (Italics mine, The Comedy of

Oedipus, p. 329)

As a result, Senefru is seen "dashing" among the crowd chanting "loudly and enthusiastically, and with true harmony" (Stage direction, p. 329), yet, "his whole heartedness and enthusiasm gradually change to bitter weeping" (Stage direction, p. 329). Senefru's feigned hoarseness is his tool of resistance. This functions as an "attitudinal marker" -to use Elam's word- " [which is] indicative not of the act intended but of the attitude adopted (towards the world, the addressee ....) in speaking -head nods, finger wags, eyebrow movements ...." (Elam, 1980, p. 78). Moreover, the shift -from "detachment to "dashed in" to taking "refuge in a corner .... dropping into sitting position, and weeping quietly" (Stage direction, p. 329) underscores two opposing voices: "singing enthusiastically" and "bitter weeping". This is the outcome of Awalih's threat of physical torture as exemplified in "I am going to clean your ears". Here, Awalih's will prevails because he uses his authority as a means of pressurizing the playwright. That is to say, Awalih's voice takes an increasingly ferocious edge and the situation escalates into full scale terrorism. Thus, I approve of AlSharqawy's endeavor to change the union between Oedipus, Creon and Tiresias. Al-Sharqawy makes Senefru in the place of Tiresias so as to assert the instigating role real art can play to liberate man from fear (Megaly, 1984, p. 36). 
In these two encounters, Awalih's vocalic qualities are signifiers of defective speeches since the audience are fully aware of their contradiction. On this point, Esslin argues that All speeches in drama .... produce meaning on several levels. While communicating a given meaning from one character to another, the same sentence will, in addition, convey another, and perhaps, dramatically more important meaning to the audience .... Every word of dramatic dialogue thus carries (at least) a double charge: the factual meaning of the words, on the one hand; the information they yield about the character of the speaker on the other. (Esslin, 1987, p. 82)

Awalih's performance and in particular his paralinguistic features are responsible for this "double charge" and the decoding process is, therefore, continuous since each new line uttered by Awalih will put an additional touch to the depiction of his character with all its dialectic of inner contradiction and inconsistencies. Awalih's paralinguistic features serve to "individualize character" (Esslin, 1987, p. 82) to use Esslin's words since they are index signs of his personal speech-pattern, vocabulary and professional jargon.

\section{Conclusion}

Salem's revisited play can be examined as a postmodern discourse in establishing an ironic dialogue with the past and in its mixing of high tragedy and low comedy. In this sense, The Comedy of Oedipus is itself an open text inviting different readings and interpretations. Intertextuality, as a postmodern strategy, underscores the concept of relationality, thereby, the view of literature is shifted from a "container of meaning" to "a space in which a potentially vast number of relations coalesce" (Allen, 2011, p. 12). The Comedy of Oedipus is a semiotic sign that marks the move from "from general intertextuality to textuality within social discourse" (Juvan, 2008, p.108) which is also called "explicit" theories of intertextuality (Juvan, 2008, p.111)- a term relating to the strive for more concrete and valid concepts within intertextuality. Finally, Salem's tectonic structure rests chiefly upon parallel and contrasting scenes within a circular technique to expose power-politics which unjustly legitimizes violence. Salem also makes a useful use of Brechtian formalistic devices through the incorporation of songs, addresses to the audience and the use of projections so as to produce the "A-effect" which is defined by Brecht himself: "a representation that alienates [which] recognize its subject, but at the same time makes it seem unfamiliar" (Italics mine, Brecht, 1964, p. 192). This "unfamiliar" is the key to 'replay' master narratives in order to renegotiate the current reality. This is epitomized in the new depiction of Salem's Oedipus who acts as a symbol of dictatorship. Therefore, "the body is symbolic to the extent that on stage", as De Toro argues, "it becomes a machine producing signs which invoke the collective, cosmological and universal thematics of man" (De Toro, 1995, p. 85).

\section{Biography:}

Marwa Essam Eldin Fahmi Al-Khayat is an Associate Professor of Comparative Literature \& Criticism at MISR University for Science \& Technology (MUST). She received her MA (2002) and PhD (2010) degrees in Postcolonial Comparative Drama from the University of Cairo. She published a number of academic articles in international journals and books on Semiotics, Stylistic Interpretations, Animation and Multi-Cultural Children's Literature. She also published a translation of Juha's Anecdotes within the paradigm of Humor and Laughter Theories. Finally, she is a reviewer in many international Canadian and Indian journals as well as a member in Arab Researcher Association in Emirates and International Ecolinguistics Association funded by the University of Gloucestershire. 


\section{References:}

[1] Allen. Graham, Intertextuality, London: Routledge, (2011)

[2] Aristotle, Aristotle's poetics. New York: Hill and Wang, (1961)

[3] Aston. Elain \& Savona. George, Theatre as a Sign System: A Semiotics of Text and Performance, London, Routledge, (1991), https://doi.org/10.4324/9781315002576

[4] Ayyad. Shukry \& Witherspoon. Nancy, Reflections and Deflections: A Study of Contemporary Arab Mind through its Literary Creations. Prime Literary Series 2, Published by Foreign Cultural Information Department, (1986)

[5] Badawi. M. M., Modern Arabic Drama in Egypt, Cambridge: Cambridge U P, (1987)

[6] Badawi. M. M., Early Arabic Drama, Cambridge: Cambridge U P, (1988)

[7] Barthes. Roland, Writing Degree Zero, Annette Lavers and Colin Smith (trans.). New York: Hill \& Wang, (1967)

[8] Barthes. Roland, Mythologies, Annette Lavers and Colin Smith (trans.). London: Granada, (1973)

[9] Bate. W. Jackson, The Burden of the Past and the English Poet, Cambridge: Harvard U P, (1970)

[10] Belsey. Catherine, Critical Practice, London: Methuen, (1980)

[11] Bloom. Harold, The Anxiety of Influence: A Theory of Poetry, New York: Oxford U P, (1973)

[12] Brecht. Bertolt (1964), A Short Organum for the Theatre, Brecht on Theatre: Development of an Aesthetic, John Willet (trans. \& ed.). New York: Hill \& Wang.

[13] Carlson. M., Theatrical Performance: Illustration, Translation, Fulfillment or Supplement?. Theatre Journal, 37(1)(1985), 5, https://doi.org/10.2307/3207181

[14] Carlson. Marvin, Theatre Semiotics: Signs of Life, Bloomington: Indiana U P, (1990)

[15] Carlson. Marvin (ed.), The Arab Oedipus: Four Plays: The Comedy of Oedipus: You who Killed the Beast. New York: Martin E. Segal Theatre Center Publication, (2005)

[16]De Toro. Fernando, Theatre Semiotics: Text and Staging in Modern Theatre, John Lewis (trans.). Frankfurt: Madrid, (1995)

[17] Elam. Keir, The Semiotics of Theatre and Drama, London \& New York: Methuen, (1980)

[18] Esslin. Martin, The Field of Drama, London: Methuen, (1987)

[19] El-Lozy. M., Brecht and the Egyptian Political Theatre, Alif: Journal of Comparative Poetics, 10(1990), 56-72.

[20] Gilbert. Helen \& Tompkins. Joanne, Postcolonial Drama: Theory, Practice, Politics, London \& New York: Routledge, (1996)

[21] Gulli Pugliatti. Paola (1976), I Segni Latenti: Scrittura Come Virtualita in King Lear. Messina \& Florence: D'Anna, Quoted in The Semiotics of Theatre and Drama by Elam, Keir. London \& New York: Methuen, 1988. 
[22] Juvan. Marko, History and Poetics of Intertextuality, West Lafayette: Purdue UP, (2008)

[23] Seleiha. Nihad (2001), Manifold Oedipus, Al-Ahram Weekly, Dec.

[24] Sophocles \& Grene. D., Oedipus the King. Chicago: University of Chicago Press, (2010)

[25] Styan. J. L., The Elements of Drama, Cambridge: Cambridge University Press, (1961)

[26] Styan. J. L., The Dark Comedy: The Development of Modern Comic Tragedy, Cambridge: Cambridge University Press, (1968)

[27] Ubersfeld. Ann, Lire Le Theatre. Paris: Editions Sociales. Quoted in Theatre Semiotics: Text and Staging in Modern Theatre by Fernando De Toro. John Lewis (trans.). Frankfurt: Madrid, (1977).

[28] Zeid. Wagdy, Bond and Stoppard Vs. Shakespeare: The Anxiety of Influence, Cairo: General Egyptian Book organization, (1990)

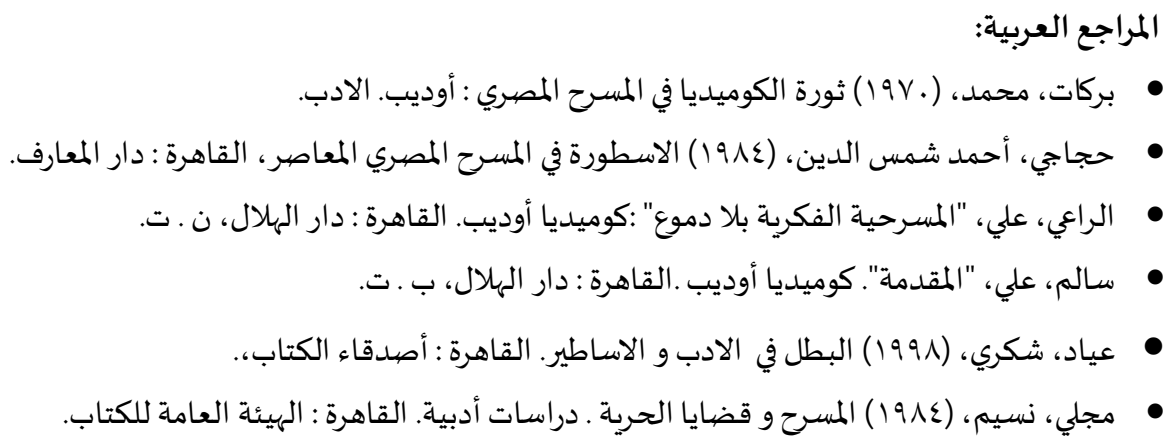

